\title{
Učestalost muške populacije u sestrinstvu kroz povijest i danas The frequency of the male population in nursing throughout history and today
}

\author{
Dijana Čizik¹, Matea Čikeš', Matea Gavranic² , Tanja Marjanovič3, Petra Mlikota ${ }^{4}$ \\ 1Dom zdravlja Dubrovnik, Sanitetski prijevoz, Dr. Ante Starčevića 1, 20000 Dubrovnik, Republika Hrvatska \\ ${ }^{2}$ Zavod za hitnu medicinu Dubrovačko-neretvanska županija - ispostava Orebić, Ulica Kralja Tomislava 22, 20250 Orebić, Republika Hrvatska \\ 3Opća bolnica Dubrovnik / Odjel za Neurologiju, Dr. Roka Mišetića 2, 20000 Dubrovnik, Republika Hrvatska \\ ${ }^{4}$ Sveučilište u Dubrovniku, Studij sestrinstva, Stablinac XI/46, 22211 Vodice, Republika Hrvatska
}

\begin{abstract}
Sažetak
Autori opisuju uloga muške populacije u razvoju sestrinstva te specifičnosti utjecaja uvriježenog mišljenja u općoj populaciji o sestrinstvu. Također opisuju recentne promjene u sestrinstvu s posebnim naglaskom na povećanje broja osoba muške populacije u današnjem sustavu sestrinstva.
\end{abstract}

Ključne riječi: sestrinstvo • medicinska sestra - medicinski tehničar • feminizacija • predrasude

Kratki naslov: Muška populacija i sestrinstvo

\begin{abstract}
The authors describe the role of the male population in the development of nursing and specificity of the influences common opinion in the general population of nursing. They also describe recent changes in nursing with a focus on increasing number of the male population in today's system of nursing.
\end{abstract}

Keywords: nursing $•$ nurse-medical technician • feminization • bias

Running head: Male population and nursing
U općoj populaciji danas je uvriježeno mišljenje da je sestrinstvo zanimanje u kojoj se isključivo zapošljavaju osobe ženskog spola. Ističemo da u spisima o povijesti sestrinstva postoje podatci kako su brigu o oboljelima i umirućima, prije feminizacije sestrinstva, isključivo provodile osobe muškog spola. Danas je uvriježeno mišljenje da moderno sestrinstvo započinje na osnovama bilješki Florence Nihtingale [1820.-1910.], ali i da je zanimanje isključivo namijenjeno osobama ženskog spola. Međutim, potrebno je istaknuti kako se u današnjem sestrinstvu zapošljava veliki broj osoba muškog spola. Stoga, svrha ovog članka povećanje je obima znanja opće populacije o prevalenciji osoba muškog spola u sestrinstvu te smanjenje predrasuda o tome kako je sestrinstvo isključivo ženska profesija.

S velikim zanimanjem pročitali smo članak "Sestrinstvo - ženska profesija", autora iz Opće bolnice Pula [1]. Uporabom citata iz međunarodne literature autori opisuju ulogu muške populacije u razvoju sestrinstva te specifičnosti utjecaja uvriježenog mišljenja u općoj populaciji o sestrinstvu. Također opisuju se recentne promjene u sestrinstvu $s$ posebnim naglaskom na povećanje muške populacije $u$ današnjem sestrinstvu [2].

Autori temeljem sustavnog pregleda literaturnih navoda opisuju postojanje potrebe mijenjanja uvriježenog mišljenja u općoj populaciji kako je sestrinstvo stručno-znanstvena grana u kojoj učestvuju isključivo osobe ženske spola.
Potrebno je naglasiti [3] da je moderno sestrinstvo profesija u kojoj je ženska populacija zastupljenija. Međutim, potrebno je istaknuti da postoje podatci kako su u tijeku povijesnog razvoja sestrinstva pripadnici muškog spola dali značajan doprinos razvoju sestrinstva. Tako su 250. godine prije Krista u Indiji školu za njegovatelje pohađali samo pripadnici muškog spola. Petsto godina kasnije, u Bizantskom carstvu osnovana je služba za upotrebu metoda zdravstvene njege $u$ hospiciju, a osobe muškog spola imale su dominantnu ulogu [4]. U trećem stoljeću u Aleksandriji, za vrijeme pojave velike kuge postoje parabolani, tj. Članovi kršćanskog bratstva koji volonterski zbrinjavaju bolesne i ozlijeđene te ukapaju mrtve osobe [5].

Danas je uvriježeno mišljenje kako je Florence Nightingale [1820.-1910.] začetnik modernog sestrinstva. Potrebno je napomenuti kako je ona smatrala da radne zadatke medicinske sestre može obavljati isključivo osoba ženskog spola.

Neka od načela modernog sestrinstva sažeta su u čimbenicima koje je ona zahtijevala od učenika koji su bili polaznici njezine škole za obrazovanje medicinskih sestara. Od učenica je zahtijevala da budu poštene, točne, pouzdane, blage, mirne, tihe, uredne, čiste, vesele i strpljive [6, 7]. Na osnovu spomenutih čimbenika nastao je etički prototip medicinske sestre kao žene koja je odgovorna, hrabra, požrtvovna, radišna, majčinski nježna i pokorna liječniku. 
Prema Cockerhamu, stereotip, tj. model sestrinstva koji je razvijala Nightingale osnova je modela današnjeg sestrinstva, a ovjekovječio je ženu u ulozi medicinske sestre, a medicinsku sestru u ulozi žene.

Danas je verificirano kako u sestrinstvu postoji značajno povećanje broja muških osoba, međutim u značajnom obimu opće populacije prevladava mišljenje kako je sestrinstvo isključivo profesija u kojoj su zaposlene osobe ženskog spola [8].

Sociološka znanost opisuje da su osobine muških osoba: snaga, agresivnost, samokontrola, menadžerstvo, kompetitivnost, objektivnost, upornost, hrabrost i dominacija.

Prema opisanim čimbenicima zaključujemo da muške osobe imaju veći stupanj zainteresiranosti prema tehničkim zanimanjima, poslovima s višim društvenim statusom, većim osobnim dohotkom te onima za koja je potrebna inicijativa i kompetitivnost [9].

U sestrinskoj zajednici uvriježeno je mišljenje da osobe muškog spola rade na poslovima u sestrinstvu gdje je potrebno ulaganje većeg fizičkog napora (primjerice: psihijatrija, kirurgija, anestezija, operacijske dvorane, hitni bolnički prijem), dok za provođenje radnih aktivnosti na pedijatrijskim i ginekološkim odjelima nisu zadovoljavajući.

Napominjano, kako se u domaćoj literaturi opisuju i stavovi krovne Hrvatske sestrinske organizacije [Hrvatska komora medicinskih sestara - HKMS], a prema istima postoje nezadovoljavajući primjeri u svakodnevnoj praksi.

Primjerice logotip HKMS-a sadržava ljubičastu boju, licenca [odobrenje] za samostalan rad također je ljubičaste boje, kao i članske iskaznice. Danas u svjetskim sestrinskim organizacijama postoje smjernice i/ili preporuke da se izbjegava upotreba tzv. spolno obojenih simbola $[8,9]$.

Primjerice, zašto su radne uniforme medicinskih sestara, a ne i tehničara obojene plavo? Nije li to spolno obojeni simbol za muškarce?

Posebnu pažnju treba obratiti na uvriježeno mišljenje kako je sestrinstvo isključivo zanimanje u kojem su zaposlenici osobe ženskog spola, a koje proizlazi iz jezične sintagme.

Stoga u svrhu boljeg razumijevanja opisane problematike u citiranom članku, te provođenja sličnih istraživanja u budućnosti navodimo: pojam "sestra" objašnjava nešto blisko, intimno, toplo, obiteljsko, ali nadasve žensko, a "sestrinstvo" kao određenu pripadnost određenoj grupaciji. Značajan obim današnje opće populacije ima uvriježeno mišljenje da je sestrinstvo isključivo profesija sa ženskim zaposlenicima, a što je u značajnom obimu uzrokovano nazivom koje u korijenu sadržava riječ "sestra".

Danas je verificirano da je u sestrinstvu značajan broj djelatnika muškog spola, te da značajno veći broj istih pohađa specijalizirane edukacijske ustanove za sestrinstvo.
Razvojem sestrinstva kao samostalne profesije, danas postoji mogućnost znanstvenog napredovanja djelatnika te je i to jedan od značajnih čimbenika koji uzrokuje smanjenje obima o potrebi dijeljenja na tzv. muške i ženske poslove u sestrinstvu.

U strukturi zaposlenika u sestrinstvu veći je broj osoba ženskog spola, ali su danas osobe muškog spola u svim područjima vertikalne hijerarhije u sestrinstvu.

Određeni stereotipi koji su uvriježeni o sestrinstvu uzrokovani su jezičnom simboličkom razinom koju označava riječ "sestra", odnosno "sestrinstvo". Kada se ovome pridoda da je broj osoba muškog spola u sestrinstvu u stalnom porastu [10], opravdano se

postavlja pitanje je li sestrinstvo isključivo ženska profesija. Odgovor mora biti NE.

Točni su navodi autora da stereotipi proizlaze iz jezične sintagme kao i društvenog konteksta . Nažalost, danas postoje brojne predrasude, ali je znanstveno, povijesno i stručno verificirano da osnova sestrinstva nije podjela na muško ili žensko. Stoga u svrhe boljeg razumijevanja zaključaka opisanog članka autora iz Pule, potrebno je istaknuti kao je osnova/bit sestrinstva humanost i predanost profesiji, i to neovisno o spolu.

\section{Zahvala/Acknowledgement}

We thank Narcis Hudorovic, MD.PhD for assistance with [IMRaD technique, methodology], and] for comments that greatly improved the manuscript.

\section{Literatura/References:}

[1] Licul R. Sestrinstvo-ženska profesija? JAHR. 2014;5(9):183-192

[2] Evans J. Man in nursing: issues of gendersegregation and hidden advantage, Juornal of Advanced Nursing, 1997; 26(2), 226-231

[3] Mackintosh C. A historical study of men in nursing, Juornal of Advanced Nursing, 1997;26(2):32-236

[4] Quan K. The Role of Men in Nursing Today 2012., Avalaible at: http:// nursinglink.monster.com/benefits/articles/13045-the-.role-of-menin-nursing-today, Retrieved at December $23^{\text {rd }} 2015$.

[5] Mackintosh C. A historical study of men in nursing, Juornal of Advanced Nursing 1997;26(2): 232-236

[6] Šegota I. Etika sestrinstva, Pergamena, 1997. Zagreb

[7] Kalauz S. Sestrinska profesijau svjetlubioetičkog pluriperspektivizma, Pergamena i Hrvatska komora medicinskih sestara, 2011. Zagreb

[8] Cerjan-Letica G, Letica S, Babić-Bosanac S,Mastilica M, Orešković S., Medicinska Sociologija, Medicinska naklada, 2003. Zagreb.

[9] Egeland JW, Brown JS. Sex role stereotyping and role strain of male registered nurses, Research in Nursing-Health, 1998;1(4):257-267.

[10] Šonje J. Riječnik hrvatskog jezika, Leksikografski zavod Miroslav Krleža i Školska knjiga, 2000. 